\title{
INFLUENCE OF USING OLIVE CAKE MEAL WITH OR WITHOUT SODIUM BICARBONATE ON PRODUCTIVE PERFORMANCE OF GROWING NEW ZEALAND WHITE RABBITS
}

\author{
I.A. Azazi ${ }^{1}$, Haiam S. Abd EL-Haliem ${ }^{2 *}$, S. Gadelrab ${ }^{1}$, H.M. EL-Komy ${ }^{1}$, A.S. Ahmed ${ }^{1}$ and \\ M.M.M. Ouda ${ }^{1}$ \\ 1- Animal Production Research Institute, Agricultural Research Center, Dokki, Giza, Egypt, 2- Animal \\ Production Department, Faculty of Agriculture, Suez Canal University, Ismailia, Egypt, PO Box 41522. \\ *Corresponding author: Tel: 00201020517974; E-mail:haiam65@yahoo.com
}

Received: 17/10/2019

Accepted: $18 / 12 / 2019$

\section{SUMMARY}

The present experiment was carried out to investigate the possibility of incorporating 10 and $20 \%$ of olive cake meal (OCM) with or without $0.25 \%$ and $0.50 \%$ sodium bicarbonate $\left(\mathrm{NaHCO}_{3}\right)$ in the rabbit diets and their effects on growth performance, carcass traits, blood constituents, nutrient utilization and economical efficiency of growing rabbits. A total of 105 unsexed, New Zealand White (NZW) weaned rabbits of 4 weeks of age were randomly assigned to 7 equal experimental groups (15 rabbits each). Rabbits were housed individually in wire mesh cages. The first treatment served as control without additives. The $2^{\text {nd }}, 3^{\text {rd }}$, and $4^{\text {th }}$ treatments contained $10 \%$ OCM supplemented with zero, 0.25 and $0.50 \% \mathrm{NaHCO}_{3}$, respectively. The $5^{\text {th }}$, 6th and $7^{\text {th }}$ treatments contained $20 \%$ OCM supplemented with zero, 0.25 and $0.50 \% \mathrm{NaHCO}_{3}$, respectively. Results revealed that rabbits fed diet supplemented with $10 \%$ OCM with $0.25 \mathrm{NaHCO}_{3}$ recorded the highest value of final body weight, total gain, daily weight gain and performance index (\%). In addition, diets with 10 and 20\% OCM with 0.25 or $0.50 \mathrm{NaHCO}_{3}$ numerically increased digestibility coefficient of $\mathrm{CP}$ and significantly increased $(P \leq 0.01)$ digestibility coefficient of $\mathrm{CF}$ as compared with other groups. Whereas, 20\% OCM without $\mathrm{NaHCO}_{3}$ attained the worst nutrient digestibility for all parameters studied.

Also, rabbits fed $10 \% \mathrm{OCM}$ with or without $\mathrm{NaHCO}_{3}$ were more efficient in feeding utilization than the others. Furthermore, Rabbits fed $10 \%$ OCM plus 0.25 or $0.50 \% \mathrm{NaHCO}_{3}$ diets had the highest significance $(P \leq 0.01)$ in carcass \% compared with others. Rabbits fed diet supplemented with $10 \%$ OCM without $\mathrm{NaHCO}_{3}$ had the lowest values of all traits.

Furthermore, the differences for serum cholesterol, triglycerides and albumin concentrations were highly significant $(P \leq 0.01)$ whereas, the differences were significant $(P \leq 0.05)$ for $A L T$, and non significant for total lipids, total protein, globulin, $A / G$ and AST. Data on serum cholesterol concentrations were greater in for the groups that were fed 10 or $20 \%$ OCM without $\mathrm{NaHCO}_{3}(P \leq 0.01)$ compared with others.

There were an improvement in economical efficiency (EEf) and relative economical efficiency (REEf) for rabbits fed diets $10 \%$ OCM, without or with $\mathrm{NaHCO}_{3}$, as compared with other groups.

In conclusion, results of this study indicated that inclusion of olive cake meal (OCM) in growing rabbit's diet at a level 10\% with or without sodium bicarbonate may be useful and have significant impact on growth performance, carcass characteristics, blood components and economical efficiency.

Keywords: Olive cake meal, sodium bicarbonate, growth performance, digestibility coefficients, blood constituents, economical efficiency.

\section{INTRODUCTION}

Shortage of animal protein is a severe problem in developing countries, including Egypt. Domestic rabbits may provide a valuable solution to that difficulty because of their ability to utilize forages and agricultural by-products without the need to use grains and other concentrated feeds.

Olive cake meal (OCM) is the raw material resulting after extraction of olive oil. It composed of a mixture of skins, pulp, seeds representing $35 \%$ of the weight of the pressed olives (Dal Bosco et al., 2007) and present in big amounts locally.

In animal feed, olive cake can be used (Heuzé et al., 2014). However, it contains high amounts of crude fiber ( 220 to $350 \mathrm{~g} / \mathrm{kg}$ ), which can restrict its use in the chicken, but may be useful in ruminant and rabbits feeding (Rupić et al., 1999). Furthermore, the olive cake is a potentially useful source of indigestible fiber in growing rabbits to avoid digestive disorder by allowing a better balance between the various fiber fractions of the feed (Carraro et al., 2005). Chemical composition of OCM was determined to be: Crude Protein $6.79 \%$, Crude Fiber $33.32 \%$, Crude Fat $18.92 \%$. (Abdallah et al., 2015). In a previous study by Azazi et al. (2018), who found that, the average composition of OCM was (\% on as fed basis): dry matter (91.68), organic matter (83.38), ash (8.30\%), neutral detergent fiber $(55.10 \%)$, acid detergent fiber $(42.33 \%)$, acid detergent lignin (17.90\%), 
hemicellulose $(12.77 \%)$, cellulose $(12.77 \%)$, crude protein $(6.70 \%)$, ether extract $(5.90 \%)$ and digestible energy $(1900 \mathrm{k} \mathrm{cal} / \mathrm{kg})$ and tannins $(7.80$ $\%$ ). El-Sheikh (2012) discovered elevated tannin levels in OCM (12.05\%). The olive cake meal's chemical analysis varies widely due to the method of oil extraction, harvest year, and olive geographical origin of olives (Moic et al., 2007).

Many prior studies have shown that dietary tannin $s$ lead to lower weight gains and poor feed efficiency in chicken (Ahmed et al., 1990; Santos-Buelga and Scalbert, 2000). Ahmed et al. (1990) noted that the growth of the birds and digestibility of nitrogen was adversely affected by the tannin-containing diets. They also reported a significant increase $(\mathrm{P} \leq 0.05)$ in pancreas weight per unit of live weight with increased concentrations of nutritional tannins. While, liver weight remained un-affected, when growing broiler fed diets containing vegetable tannins at levels of $13.5,25$ and $50 \mathrm{~g} / \mathrm{kg}$.

Dietary tannins inhibit intestinal absorption and tr ansport of simple sugars, amino acids and minerals (Kim and Miller, 2005). Mahmood et al. (1997) and Mahmood et al. (2006) noted that the presence of salseed meal tannins in fowl diets results in lower protein digestibility, reduced digestive enzyme activity in intestinal lumen (trypsin, chymotrypsin, $\alpha$ amylase, dipeptidase, and disaccharidases) and depressed growth of chicken. Several chemical treatments (alkaline, acidic or oxidative agents) have been used to enhance the nutritional value of OCM. Alkali therapy was studied (sodium hydroxide, ammonia and urea) but the findings were more or less satisfactory (Rowghani et al., 2008). Mahmood et al. (2007) reported that the treatment of salseed meal with sodium bicarbonate $(0.67 \mathrm{M})$ and acetic acid $(0.67 \mathrm{M})$ therapy are more efficient in decreasing the content of hydrolysable and condensed tannins compared to distilled-water and polyvinyl-pyrolidone (PVP). Also, elucidated that sodium bicarbonate solution treatment is more economical and easier to use than acid treatment. Azazi et al. (2018) noted that using OCM at $10 \%$ supplemented with $0.1 \%$ citric acid could be recommended to improve growth performance, feed utilization and economic return of growing rabbits production.

Therefore, the aim of the present study was to investigate the possibility of incorporating 10 and 20 $\%$ of olive cake with or without $0.25 \%$ and $0.50 \%$ sodium bicarbonate in the rabbit diets and their effects on productive performance of growing rabbits.

\section{MATERIALS AND METHODS}

The present work was been done at the Experimental Station of Inshas, Animal Production
Research Institute, Egypt. A total of 105 unsexed, New Zealand White (NZW) weaned rabbits of 4 weeks of age were randomly assigned to 7 equal experimental groups (15 rabbits each). Rabbits were housed individually in wire mesh cages. Olive cake meal (OCM) was incorporated in rabbit diets at levels $0,10,20 \%$, without or with sodium bicarbonate $\left(\mathrm{NaHCO}_{3}\right)$ supplementation at levels $0.25,0.50 \%$. The first treatment served as a control without OCM or, $\mathrm{NaHCO}_{3}$ supplementation. The $2^{\text {nd }}, 3^{\text {rd }}$, and 4 th treatments contained $10 \%$ OCM supplemented with zero, 0.25 and $0.50 \% \mathrm{NaHCO}_{3}$, respectively. The $5^{\text {th }}$, $6^{\text {th }}$ and $7^{\text {th }}$ treatments contained $20 \%$ OCM supplemented with zero, 0.25 and $0.50 \% \mathrm{NaHCO}_{3}$, respectively. All experimental diets were approximately isocaloric, isonitrogenous and isofiberous and were formulated to meet the recommended nutrient requirements of rabbits, according to (Agriculture Ministry Decree, 1996). Formulation and calculated analysis of the experimental basal diets are shown in Table (1).

Rabbits were housed in galvanized metal wire cages, equipped with feeders and automatic nipple drinkers. Food and water were accessible, ad libitum. The rabbits were held under the same conditions of environment, management and hygiene

During the experimental period which lasted for $f$ orty days, individual live body weight and feed consomption were recorded. Body weight gain and feed conversion ratio were calculated. Also, the performance index (PI \%) was calculated on the basis of (North, 1981), as follows: PI = Live body weight $(\mathrm{kg})$ / Feed conversion X 100. Daily mortality of rabbits were and number of dead rabbits was recorded.

\section{Digestibility Experiment:}

A digestibility experiment was conducted at the $\mathrm{e}$ nd of the feeding trial to determine the apparent diges tibility coefficients of experimental diets, by using 21 rabbits (3 from each group), kept separately in metabolic cages that allow feces and urine separation. The diet of each rabbit was weighted in a plastic bags and was offered once daily at 8.00 a.m. The digestibility experiment consisted of an adaptation period of 10-day period followed by a 7-day collection period. During the collection period, total daily excreted feces were weighed and oven dried at $65^{\circ} \mathrm{C}$ for $48 \mathrm{~h}$. At the end of the collection period, $20 \%$ of daily dried feces of each rabbit were mixed, ground and stored in plastic vials for laboratory analysis. Samples of feeds and dried feces were chemically analyzed according to A.O.A.C (2000). The apparent digestibility coefficients of DM, OM, $\mathrm{CP}, \mathrm{CF}, \mathrm{EE}$ and NFE of experimental diets were estimated. 
Table 1. Ingredients and calculated chemical composition of the experimental diets

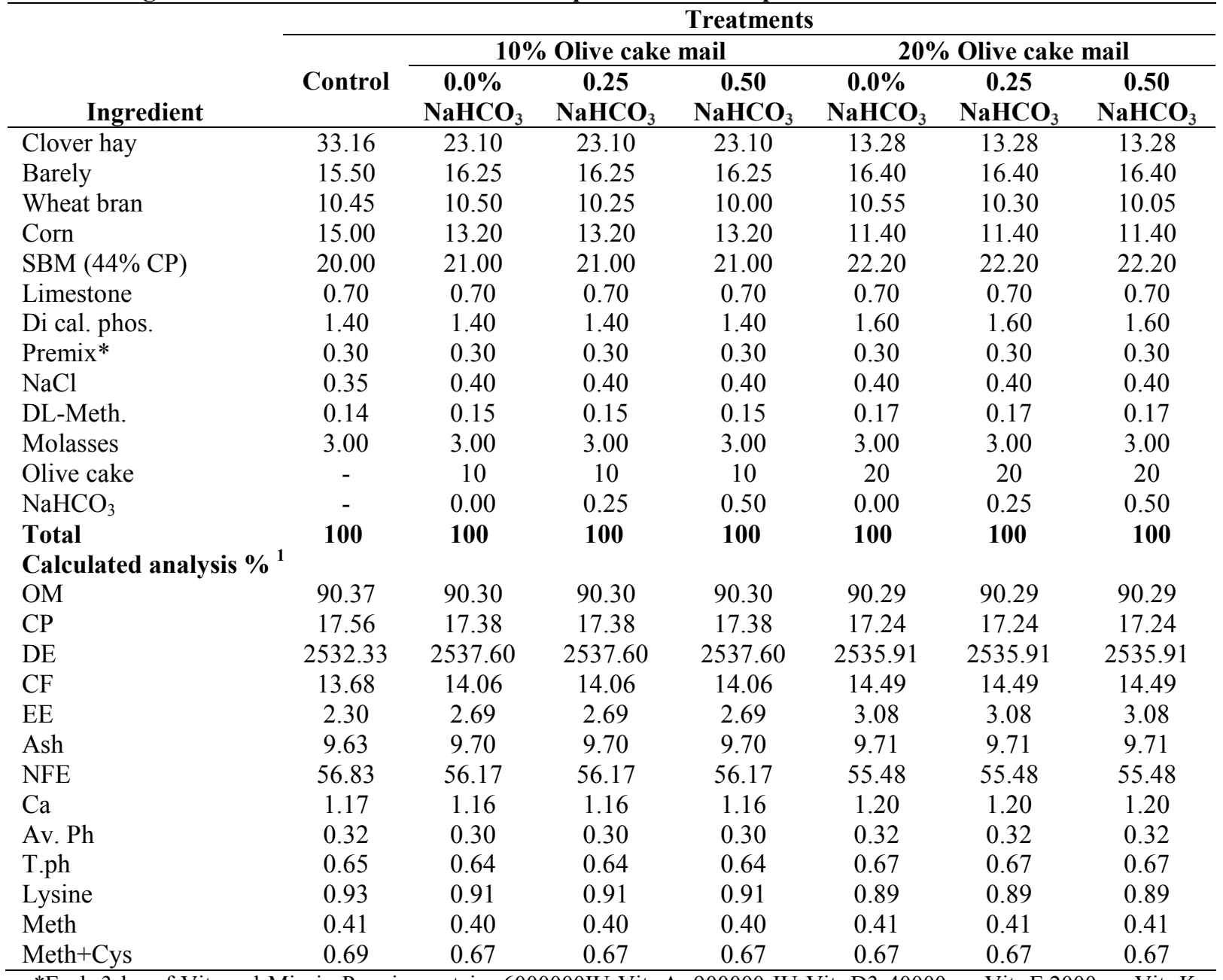

*Each 3 kg of Vit. and Min in Premix contain: 6000000IU Vit. A, 900000 IU Vit. D3 40000mg Vit. E,2000mg Vit. K, 2000mg Vit.B1, 4000mg Vit. B2, 2000mg Vit. B6, 10mg Vit. B12, 50000mg Niacin, $10000 \mathrm{mg}$ pantothenic acid, 50mg Biotin, 3000mg Folic acid, $250000 \mathrm{mg}$ Choline, 50000mg Zn, 8500mg Mn, 50000mg Fe, 50000mg Cu, 200mg I, 100mg Se and 100mg Co. 1= According to Feed composition for animal and poultry feed stuff used in Egypt (2001).

\section{Slaughtering parameters:}

Five rabbits were randomly chosen from each gro up at the end of the growth trial and slaughtered according to Cheeke (1987) to study the different carcass characteristics as $\%$ of live body weight.

\section{Blood testing parameters:}

At slaughter, blood samples were collected from each rabbit to estimate blood constituents. By centrifugation, serum was segregated at 3000 r.p.m. for $15 \mathrm{~min}$. and frozen until analysis at $-20^{\circ} \mathrm{C}$. Serum cholesterol, total lipids, triglycerides, total protein, albumin, alanine amino transferase (ALT) and aspartate amino transferase (AST) levels were colorimetrically determined using commercial kits. By subtracting albumin values of total protein values, the globulin values were obtained.

\section{Chemical analysis:}

The chemical composition of the diets and dried feces were analyzed according to A.O.A.C (2000). Total digestible nutrients (TDN) was calculated according to the classic formula of Cheeke et al. (1982).

\section{Economical efficiency (EEf):}

The economical efficiency (\%) was calculated on the basis of input-output analysis based upon the differences in both growth rate and feeding costs and was determined by the following formula:

Economical efficiency $\%=$ Net revenue/ Total feed cost)* 100

\section{Statistical analysis:}

Data were subjected to analysis for significance by a one-way ANOVA model (as a completely randomized design) using the General Linear Models (GLM) procedures of SPSS (IBM SPSS statistics, version 22, 2018, USA.). The following mathematical model used was : $\mathbf{Y}_{\mathbf{i j}}=\boldsymbol{\mu}+\mathbf{t}_{\mathbf{i}}+\mathbf{e}_{\mathbf{i i}}$ where: $\mathbf{Y}_{\mathrm{ij}}=$ the observation on the $\mathrm{jth}$ individual from the $\mathrm{i}^{\text {th }}$ treatment; $\boldsymbol{\mu}=$ the overall mean; $\mathbf{t}_{\mathbf{i}}=$ the fixed effect of the $i^{\text {th }}$ treatment; $\mathbf{e}_{\mathbf{i j}}=$ the random error associated with the individual $\mathrm{ij}$.

Treatments differences were considered significant at $\mathrm{P} \leq 0.05$ and $\mathrm{P} \leq 0.01$ for all measurements. Means comparisons were performed using Duncan's multiple range tests (Duncan, 1955). 


\section{RESULTS AND DISSECTION}

\section{Growth performance:}

Data on growth performance of NZW rabbits as affected by dietary OCM with or without $\mathrm{NaHCO}_{3}$ supplementation are summarized in Table (2). Except for the initial body weight, there were highly significant $(\mathrm{P} \leq 0.01)$ differences between treatments in all parameters studied. It could be noticed that, rabbits fed diet supplemented with $10 \%$ OCM with $0.25 \mathrm{NaHCO}_{3}$ recorded the highest value of final body weight $(1800 \mathrm{~g})$, total gain, daily weight gain and Performance index (\%). While, rabbits fed diets contained $20 \%$ OCM with or without $\mathrm{NaHCO}_{3}$ at levels 0.25 or $0.50 \%$ gave the lowest values for the same parameters. Also, rabbits fed control diet recorded the highest $(\mathrm{P} \leq 0.01)$ daily feed intake (FI) compared to the reset treatments. Furthermore, the results in Table (2) showed that the values of FCR for groups fed diets with $10 \%$ OCM with or without $\mathrm{NaHCO}_{3}$ were the best. While, rabbits fed the control diet or diets with $20 \%$ OCM with or without $\mathrm{NaHCO}_{3}$ had the poorest FCR values. The results indicated that rabbits fed $10 \%$ OCM with or without $\mathrm{NaHCO}_{3}$ were more efficient in feeding utilization than other treatment groups. Our results are in agreement with those reported by Azazi et al. (2018) who showed that the addition of OCM at $10 \%$ plus $0.1 \%$ citric acid (CA) to growing rabbit diets significantly $(\mathrm{P} \leq 0.01)$ increased live body weight $(\mathrm{LBW})$, daily weight gain (DWG) and significantly $(\mathrm{P} \leq 0.01)$ decreased $\mathrm{FI}$ and improved feed conversion ratio (FCR). They noted that the highest FI was recorded by rabbits fed control group (basal diet without additives), whereas the lowest FI was for rabbit groups fed diet with 10\% OCM without CA. Also, Walaa et al. (2016) reported that feeding rabbits on diets with $30 \%$ OCM plus $1 \%$ bentonite significantly resulted in the best final body weight, daily weight gain and feed conversion ratio. However, feed intake was not significantly affected by the different treatments when growing NZW rabbits fed diets with 30 and $60 \%$ of OCM without or with bentonite at 0.5 or $1 \%$. In addition, Mvan and Suresh (2014) concluded that citric acid supplementation at $0.9 \%$ in the diet enhanced the daily weight gain, the efficiency of feed utilization of crossbred pigs. Although, Mousa and Abd El-Samee (2002) did not show any significant differences in live body weight and body weight gain in rabbits fed diets contained $0,10,20 \%$ olive pulp meal. Similarly, El-Kerdawy (1997) found that there were no significant differences in live body weight and weight gain of rabbits given diets contained 5,10 and $15 \%$ olive pulp. While, Balnave and Oliva (1991) noted that diets supplemented with $\mathrm{NaHCO}_{3}$ in diets or drinking water produced a significant improvement in bird production response.

The improvement in growth performance for rabbits fed diets supplemented $\mathrm{NaHCO}_{3}$ than rabbits fed diets without $\mathrm{NaHCO} 3$ may be attributed to reduction of hydrolysable and condensed tannins content. Thus, it improves the activity of digestive enzymes and increases the efficiency of feed utilization.

Table 2. Growth Performance of growing rabbits as affected by dietary treatments (Means \pm SE)

\begin{tabular}{|c|c|c|c|c|c|c|c|c|}
\hline \multirow[b]{3}{*}{ Parameters } & \multicolumn{7}{|c|}{ Treatments } & \multirow[b]{3}{*}{ Sig. } \\
\hline & \multirow[b]{2}{*}{ Control } & \multicolumn{3}{|c|}{$10 \%$ Olive cake meal } & \multicolumn{3}{|c|}{$20 \%$ Olive cake meal } & \\
\hline & & $\begin{array}{c}0.0 \% \\
\mathrm{NaHCO}_{3}\end{array}$ & $\begin{array}{c}0.25 \\
\mathrm{NaHCO}_{3}\end{array}$ & $\begin{array}{c}0.50 \\
\mathrm{NaHCO}_{3}\end{array}$ & $\begin{array}{c}0.0 \% \\
\mathrm{NaHCO}_{3}\end{array}$ & $\begin{array}{c}0.25 \\
\mathrm{NaHCO}_{3}\end{array}$ & $\begin{array}{c}0.50 \\
\mathrm{NaHCO}_{3}\end{array}$ & \\
\hline Initial body Wt (g) & 551.33 & 557.00 & 547.00 & 558.67 & 561.00 & 552.33 & 557.00 & \\
\hline & \pm 13.53 & \pm 12.96 & \pm 15.57 & \pm 12.56 & \pm 20.02 & \pm 12.43 & \pm 12.28 & NS \\
\hline Final body Wt (g) & $1718.93^{\mathrm{b}}$ & $1721.67^{\mathrm{b}}$ & $1800.33^{\mathrm{a}}$ & $1694.33^{\mathrm{b}}$ & $1532.86^{\mathrm{c}}$ & $1531.33^{\mathrm{c}}$ & $1568.67^{\mathrm{c}}$ & $* *$ \\
\hline & \pm 34.84 & \pm 18.11 & \pm 17.67 & \pm 17.50 & \pm 23.85 & \pm 15.85 & \pm 20.69 & \\
\hline Total gain (g) & $1166.43^{\mathrm{b}}$ & $1164.67^{\mathrm{b}}$ & $1253.33^{\mathrm{a}}$ & $1135.67^{\mathrm{b}}$ & $971.79^{c}$ & $979.00^{\mathrm{c}}$ & $1011.67^{\mathrm{c}}$ & ** \\
\hline & \pm 35.44 & \pm 17.82 & \pm 17.91 & \pm 17.61 & \pm 24.63 & \pm 15.64 & \pm 20.32 & \\
\hline Daily weight gain (g) & $29.17^{\mathrm{b}}$ & $29.12^{\mathrm{b}}$ & $31.45^{\mathrm{a}}$ & $28.40^{\mathrm{b}}$ & $24.30^{\mathrm{c}}$ & $24.49^{\mathrm{c}}$ & $25.30^{\mathrm{c}}$ & ** \\
\hline & \pm 0.88 & \pm 0.45 & \pm 0.45 & \pm 0.44 & \pm 0.62 & \pm 0.39 & \pm 0.51 & \\
\hline Daily Feed intake (g) & $124.07^{\mathrm{a}}$ & $107.40^{\mathrm{cd}}$ & $114.80^{\mathrm{b}}$ & $109.13^{\mathrm{c}}$ & $104.21^{\mathrm{e}}$ & $103.60^{\mathrm{e}}$ & $106.20^{\mathrm{cd}}$ & $* *$ \\
\hline & \pm 0.84 & \pm 0.58 & \pm 0.73 & \pm 0.88 & \pm 0.59 & \pm 0.93 & \pm 0.59 & \\
\hline Feed conversion ratio ( $\mathrm{g}$ & $4.31^{\mathrm{a}}$ & $3.69^{\mathrm{b}}$ & $3.65^{\mathrm{b}}$ & $3.85^{\mathrm{b}}$ & $4.31^{\mathrm{a}}$ & $4.25^{\mathrm{a}}$ & $4.23^{\mathrm{a}}$ & $* *$ \\
\hline feed/g gain) & \pm 0.15 & \pm 0.72 & \pm 0.58 & \pm 0.76 & \pm 0.11 & \pm 0.79 & \pm 0.92 & \\
\hline Performance index $(\%)$ & $40.79^{\text {cd }}$ & $46.86^{\mathrm{a}}$ & $49.25^{\mathrm{ab}}$ & $44.24^{\mathrm{bc}}$ & $35.93^{\mathrm{e}}$ & $36.30^{\mathrm{e}}$ & $37.55^{\text {de }}$ & $* *$ \\
\hline & \pm 2.13 & \pm 1.39 & \pm 1.19 & \pm 1.25 & \pm 1.49 & \pm 1.01 & \pm 1.36 & \\
\hline
\end{tabular}

${ }^{\mathrm{a}-\mathrm{e}}$ means within each raw followed by different letters differ significantly,

$* *=\mathrm{P} \leq 0.01$ and $\mathrm{NS}=$ Non significant.

\section{Carcass characteristics:}

The results in Table (3) indicated that the treatments had a significant effect on carcass characteristics except heart and kidney \%. Rabbits fed $10 \%$ OCM plus 0.25 or $0.50 \% \mathrm{NaHCO}_{3}$ diets had the highest significantly $(\mathrm{P} \leq 0.01)$ carcass $\%$ compared with other treatments. However, there were insignificant differences in heart and kidney percentages among all treatments. Also, our results revealed that rabbits fed diet supplemented with $10 \%$ OCM without $\mathrm{NaHCO}_{3}$ had the lowest values of all traits studied, however it was the highest in preslaughter weight. Similarly, Azazi et al. (2018) reported that carcass, liver, heart, giblets and dressing percentages in rabbits fed 10\% OCM recorded higher values compared with other dietary treatments. Also, 
Walaa et al. (2016) showed that carcass traits were significantly affected by OCM inclusion. While, Bakr et al. (2019) showed that olive pulp inclusion in growing rabbits diets at varying levels $(15,20$ and $25 \%$ ) did not show any significant effect on all carcass traits. Similarly, Abd EL-Galil (2001) showed non-significant differences in carcass traits of rabbits fed either control or $20 \%$ olive pulp meal. Abou-Ela et al. (2011) found that carcass traits as percentage of pre-slaughter weight did not differ significantly with up to $28 \%$ OCM in rabbits 'diets.

Table 3. Carcass characteristics of growing rabbits as affected by dietary treatments (Means $\pm \mathrm{SE}$ )

\begin{tabular}{|c|c|c|c|c|c|c|c|c|}
\hline \multirow[b]{3}{*}{ Parameters } & \multicolumn{7}{|c|}{ Treatments } & \multirow[t]{2}{*}{ Sig. } \\
\hline & \multirow[b]{2}{*}{ Control } & \multicolumn{3}{|c|}{$10 \%$ Olive cake mail } & \multicolumn{3}{|c|}{$20 \%$ Olive cake mail } & \\
\hline & & $\begin{array}{c}\mathbf{0 . 0 \%} \\
\mathrm{NaHCO}_{3}\end{array}$ & $\begin{array}{c}0.25 \\
\mathrm{NaHCO}_{3}\end{array}$ & $\begin{array}{c}0.50 \\
\mathrm{NaHCO}_{3}\end{array}$ & $\begin{array}{c}\mathbf{0 . 0} \% \\
\mathrm{NaHCO}_{3}\end{array}$ & $\begin{array}{c}0.25 \\
\mathrm{NaHCO}_{3}\end{array}$ & $\begin{array}{c}\mathbf{0 . 5 0} \\
\mathrm{NaHCO}_{3}\end{array}$ & \\
\hline Pre-slaughter & $1678.33^{b}$ & $1811.67^{\mathrm{a}}$ & $1733.33^{b}$ & $1546.67^{c}$ & $1535.00^{c}$ & $1585.00^{\mathrm{c}}$ & $1573.33^{c}$ & $* *$ \\
\hline weight (g) & \pm 14.53 & \pm 26.03 & \pm 22.05 & \pm 26.82 & \pm 15.28 & \pm 11.55 & \pm 29.20 & \\
\hline \multirow[t]{2}{*}{ Carcass \% } & $56.91^{\mathrm{b}}$ & $50.99^{\mathrm{c}}$ & $59.84^{\mathrm{a}}$ & $60.38^{\mathrm{a}}$ & $57.67^{\mathrm{b}}$ & $57.10^{\mathrm{b}}$ & $57.66^{\mathrm{b}}$ & $* *$ \\
\hline & \pm 0.40 & \pm 0.72 & \pm 0.56 & \pm 0.98 & \pm 0.56 & \pm 0.36 & \pm 0.87 & \\
\hline \multirow[t]{2}{*}{ Liver \% } & $2.05^{\mathrm{ab}}$ & $1.82^{\mathrm{c}}$ & $2.15^{\mathrm{a}}$ & $2.17^{\mathrm{a}}$ & $1.98^{\mathrm{b}}$ & $2.02^{\mathrm{ab}}$ & $2.07^{\mathrm{ab}}$ & $* *$ \\
\hline & \pm 0.62 & \pm 0.06 & \pm 0.54 & \pm 0.34 & \pm 0.34 & \pm 0.32 & \pm 0.81 & \\
\hline \multirow[t]{2}{*}{ Heart \% } & 0.44 & 0.39 & 0.46 & 0.47 & 0.43 & 0.44 & 0.44 & \\
\hline & \pm 0.21 & \pm 0.30 & \pm 0.32 & \pm 0.39 & \pm 0.21 & \pm 0.33 & \pm 0.30 & NS \\
\hline \multirow[t]{2}{*}{ Kidney \% } & 0.22 & 0.18 & 0.21 & 0.22 & 0.20 & 0.21 & 0.21 & NS \\
\hline & \pm 0.02 & \pm 0.02 & \pm 0.02 & \pm 0.06 & \pm 0.04 & \pm 0.02 & \pm 0.02 & \\
\hline \multirow[t]{2}{*}{ Giblets \% } & $2.70^{\mathrm{a}}$ & $2.39^{\mathrm{b}}$ & $2.83^{\mathrm{a}}$ & $2.87^{\mathrm{a}}$ & $2.61^{\mathrm{ab}}$ & $2.67^{\mathrm{a}}$ & $2.73^{\mathrm{a}}$ & $* *$ \\
\hline & \pm 0.09 & \pm 0.05 & \pm 0.09 & \pm 0.13 & \pm 0.04 & \pm 0.07 & \pm 0.11 & \\
\hline
\end{tabular}

${ }^{\mathrm{a}-\mathrm{c}}$ means within each raw followed by different letters differ significantly, $* *=\mathrm{P} \leq 0.01$ and $\mathrm{NS}=$ Non significant.

Digestibility coefficients and nutritive values:

Results of nutrient digestibility coefficients and nutritive values of experimental diets are presented in Table 4. It is clearly that the incorporation of OCM in rabbit diets resulted in nonsignificant differences among treatments in digestion coefficients of dry matter (DM), organic matter $(\mathrm{OM})$, crude protein (CP), ether extract (EE) and NFE. While, the difference in digestibility coefficient of crude fiber (CF) was significant $(\mathrm{P} \leq 0.01)$. Also, results showed that digestible crude protein (DCP), total digestible nutrient (TDN) and digestible energy (DE) were not significantly affected by experimental diets. Data revealed that the rabbits received a diet supplemented with $20 \%$ OCM without $\mathrm{NaHCO}_{3}$ attained the worst nutrient digestibility for all parameters studied, followed by those rabbits received a diet supplemented with $10 \%$ OCM without $\mathrm{NaHCO}_{3}$ for $\mathrm{CF}$, EE, NFE and TDN as compared with other treatments.

Table 4. Digestibility coefficients and nutritive values of the experimental diets (Means \pm SE)

\begin{tabular}{|c|c|c|c|c|c|c|c|c|}
\hline \multirow[b]{3}{*}{ Parameters } & \multicolumn{7}{|c|}{ Treatments } & \multirow[b]{3}{*}{ Sig. } \\
\hline & \multirow[b]{2}{*}{ Control } & \multicolumn{3}{|c|}{$10 \%$ Olive cake mail } & \multicolumn{3}{|c|}{$20 \%$ Olive cake mail } & \\
\hline & & $\begin{array}{c}\mathbf{0 . 0 \%} \\
\mathrm{NaHCO}_{3}\end{array}$ & $\begin{array}{c}0.25 \\
\mathrm{NaHCO}_{3}\end{array}$ & $\begin{array}{c}0.50 \\
\mathrm{NaHCO}_{3}\end{array}$ & $\begin{array}{c}\mathbf{0 . 0 \%} \\
\mathrm{NaHCO}_{3}\end{array}$ & $\begin{array}{c}0.25 \\
\mathrm{NaHCO}_{3}\end{array}$ & $\begin{array}{c}0.50 \\
\mathrm{NaHCO}_{3}\end{array}$ & \\
\hline \multirow[t]{2}{*}{$\mathrm{DM}$} & 64.54 & 64.37 & 64.62 & 64.73 & 63.99 & 66.69 & 65.63 & \multirow{2}{*}{ NS } \\
\hline & \pm 1.11 & \pm 1.60 & \pm 0.75 & \pm 1.14 & \pm 0.92 & \pm 1.4 & \pm 0.69 & \\
\hline \multirow[t]{2}{*}{$\mathrm{OM}$} & 65.82 & 64.92 & 65.23 & 65.47 & 64.76 & 65.36 & 65.47 & \multirow{2}{*}{ NS } \\
\hline & \pm 0.52 & \pm 0.72 & \pm 1.56 & \pm 2.15 & \pm 0.97 & \pm 1.63 & \pm 0.37 & \\
\hline \multirow[t]{2}{*}{$\mathrm{CP}$} & 74.83 & 75.68 & 76.65 & 76.96 & 74.42 & 75.33 & 74.84 & \multirow{2}{*}{ NS } \\
\hline & \pm 1.12 & \pm 2.66 & \pm 2.47 & \pm 2.16 & \pm 2.51 & \pm 1.71 & \pm 2.95 & \\
\hline \multirow[t]{2}{*}{$\mathrm{CF}$} & $31.79^{\mathrm{ab}}$ & $30.21^{\mathrm{b}}$ & $32.00^{\mathrm{ab}}$ & $34.15^{\mathrm{a}}$ & $29.99^{\mathrm{b}}$ & $33.10^{\mathrm{ab}}$ & $33.22^{\mathrm{ab}}$ & \multirow[t]{2}{*}{$* *$} \\
\hline & \pm 0.89 & \pm 0.65 & \pm 1.19 & \pm 0.34 & \pm 1.12 & \pm 1.61 & \pm 1.25 & \\
\hline \multirow[t]{2}{*}{$\mathrm{EE}$} & 65.61 & 65.03 & 66.18 & 65.14 & 64.24 & 65.78 & 65.25 & \multirow[t]{2}{*}{ NS } \\
\hline & \pm 1.87 & \pm 1.15 & \pm 1.83 & \pm 0.68 & \pm 1.58 & \pm 2.37 & \pm 0.53 & \\
\hline \multirow[t]{2}{*}{ NFE } & 75.24 & 73.75 & 74.53 & 75.55 & 72.96 & 75.65 & 75.51 & \multirow[t]{2}{*}{ NS } \\
\hline & \pm 0.99 & \pm 0.85 & \pm 1.44 & \pm 0.37 & \pm 0.67 & \pm 1.28 & \pm 0.98 & \\
\hline \multirow[t]{2}{*}{ TDN } & 63.62 & 63.09 & 63.83 & 64.70 & 62.14 & 64.34 & 64.16 & \multirow[t]{2}{*}{ NS } \\
\hline & \pm 0.48 & \pm 0.37 & \pm 0.05 & \pm 0.39 & \pm 0.34 & \pm 0.78 & \pm 0.92 & \\
\hline \multirow[t]{2}{*}{ DCP } & 12.18 & 12.36 & 12.45 & 12.56 & 12.07 & 12.41 & 12.53 & \multirow[t]{2}{*}{ NS } \\
\hline & \pm 0.20 & \pm 0.64 & \pm 0.43 & \pm 0.38 & \pm 0.43 & \pm 0.29 & \pm 0.51 & \\
\hline \multirow[t]{2}{*}{$\mathrm{DE}$} & 2511.00 & 2528.33 & 2540.33 & 2548.00 & 2507.33 & 2510.00 & 2512.00 & \multirow[t]{2}{*}{ NS } \\
\hline & \pm 23.60 & \pm 17.46 & \pm 43.80 & \pm 18.34 & \pm 17.48 & \pm 29.60 & \pm 23.64 & \\
\hline
\end{tabular}


Generally, feeding growing rabbits diets with 10 and $20 \%$ OCM with 0.25 or $0.50 \mathrm{NaHCO}_{3}$ numerically increased digestibility coefficient of $\mathrm{CP}$ and significantly increased $(\mathrm{P} \leq 0.01)$ digestibility coefficient of $\mathrm{CF}$ as compared with other groups. The improvement may be due to the binding of tannin contents of the OCM by $\mathrm{NaHCO}_{3}$, thus it improves the activity of digestive enzymes in the gut lumen. Jyothi and Sumathi, (1995) reported that $\mathrm{NaHCO}_{3}$ and sodium carbonate) $\mathrm{Na}_{2} \mathrm{CO}_{3}$ ( treatments were most effective in the destruction of anti-nutritional factors, such as tannins, phytate and trypsin inhibitors and in improving 'protein quality. The results of our study are in agreement with those reported by Azazi et al. (2018) who found that digestibility coefficients of nutrients and nutritive values improved with adding citric acid levels up to $0.2 \%$ in rabbit diets which contain OCM up to $20 \%$. In addition, The diets contain $10 \%$ or $20 \%$ OCM without citric acid recorded lower digestibility coefficients in comparison to diets supplemented by citric acid. Also, Walaa et al. (2016) decided that the inclusion of OCM in rabbit diets resulted in non-significant differences in dry matter (DM), organic matter (OM), crude protein $(\mathrm{CP})$ and crude fiber $(\mathrm{CF})$ digestibility coefficients. However, the differences were significant for the ether extract (EE) and NFE digestibility coefficients.

While, Dorbane et al. (2016) reported that the substitution of $20 \%$ of basal diet by crude OCM reduced the digestibility of organic matter and crude protein $(\mathrm{P} \leq 0.001)$.

\section{Blood constituents:}

Changes in blood components and metabolites could be used as an indicator for the nutritional and physiological status of the animal. Data presented in Table 5 showed that all serum constituents were within the normal range (Manning et al., 1994) and that OCM in the present study had significant effects on some blood constituents. The results revealed that the impacts of experimental treatments on the levels of serum cholesterol, triglycerides and albumin were highly significant $(\mathrm{P} \leq 0.01)$ whereas, the differences were significant $(\mathrm{P} \leq 0.05)$ for $\mathrm{ALT}$, and non significant for total lipids, total protein, globulin, A/G and AST.

Table 5. Serum constituents of growing rabbits as affected by dietary treatments (Means \pm SE)

\begin{tabular}{|c|c|c|c|c|c|c|c|c|}
\hline \multirow[b]{3}{*}{ Parameters } & \multicolumn{7}{|c|}{ Treatments } & \multirow[b]{3}{*}{ Sig. } \\
\hline & \multirow[b]{2}{*}{ Control } & \multicolumn{3}{|c|}{$10 \%$ Olive cake mail } & \multicolumn{3}{|c|}{$20 \%$ Olive cake mail } & \\
\hline & & $\begin{array}{c}0.0 \% \\
\mathrm{NaHCO}_{3} \\
\end{array}$ & $\begin{array}{c}0.25 \\
\mathrm{NaHCO}_{3} \\
\end{array}$ & $\begin{array}{c}0.50 \\
\mathrm{NaHCO}_{3} \\
\end{array}$ & $\begin{array}{c}0.0 \% \\
\mathrm{NaHCO}_{3} \\
\end{array}$ & $\begin{array}{c}0.25 \\
\mathrm{NaHCO}_{3} \\
\end{array}$ & $\begin{array}{c}0.50 \\
\mathrm{NaHCO}_{3} \\
\end{array}$ & \\
\hline Cholesterol (mg/dl) & $\begin{array}{c}64.63^{\mathrm{cd}} \\
\pm 4.14\end{array}$ & $\begin{array}{c}84.37^{\mathrm{ab}} \\
\pm 2.87\end{array}$ & $\begin{array}{c}63.89^{\mathrm{cd}} \\
\pm 6.56\end{array}$ & $\begin{array}{l}59.15^{\mathrm{d}} \\
\pm 2.14\end{array}$ & $\begin{array}{l}89.83^{\mathrm{a}} \\
\pm 0.90\end{array}$ & $\begin{array}{c}75.26^{\text {bc }} \\
\pm 2.90\end{array}$ & $\begin{array}{l}71.30^{\mathrm{cd}} \\
\pm 5.71\end{array}$ & $* *$ \\
\hline Total lipids (mg/dl) & $\begin{array}{c}1.89 \\
\pm 0.06\end{array}$ & $\begin{array}{c}1.97 \\
\pm 0.04\end{array}$ & $\begin{array}{c}1.80 \\
\pm 0.04\end{array}$ & $\begin{array}{c}1.87 \\
\pm 0.04\end{array}$ & $\begin{array}{c}1.99 \\
\pm 0.05\end{array}$ & $\begin{array}{l}1.97 \\
\pm 0.05\end{array}$ & $\begin{array}{c}1.88 \\
\pm 0.07\end{array}$ & NS \\
\hline $\begin{array}{l}\text { Triglycerides } \\
(\mathrm{mg} / \mathrm{dl})\end{array}$ & $\begin{array}{c}133.67^{b} \\
\pm 3.63\end{array}$ & $\begin{array}{c}141.20^{\mathrm{ab}} \\
\pm 2.91\end{array}$ & $\begin{array}{c}131.39^{\mathrm{b}} \\
\pm 3.99\end{array}$ & $\begin{array}{c}131.65^{\mathrm{b}} \\
\pm 7.95\end{array}$ & $\begin{array}{c}154.00^{\mathrm{a}} \\
\pm 2.97\end{array}$ & $\begin{array}{c}147.70^{\mathrm{a}} \\
\pm 2.48\end{array}$ & $\begin{array}{c}145.53^{\mathrm{ab}} \\
\pm 3.36\end{array}$ & $* *$ \\
\hline Total protein $(\mathrm{g} / \mathrm{dl})$ & $\begin{array}{c}6.43 \\
\pm 0.15\end{array}$ & $\begin{array}{c}6.28 \\
\pm 0.13\end{array}$ & $\begin{array}{c}6.33 \\
\pm 0.14\end{array}$ & $\begin{array}{c}6.28 \\
\pm 0.10\end{array}$ & $\begin{array}{c}5.94 \\
\pm 0.03\end{array}$ & $\begin{array}{c}6.25 \\
\pm 0.08\end{array}$ & $\begin{array}{c}6.21 \\
\pm 0.03\end{array}$ & NS \\
\hline Albumin (g/dl) & $\begin{array}{l}3.34^{\mathrm{a}} \\
\pm 0.07\end{array}$ & $\begin{array}{l}3.10^{\mathrm{bc}} \\
\pm 0.09\end{array}$ & $\begin{array}{l}3.33^{\mathrm{a}} \\
\pm 0.04\end{array}$ & $\begin{array}{l}3.20^{\mathrm{ab}} \\
\pm 0.05\end{array}$ & $\begin{array}{l}2.96^{\mathrm{c}} \\
\pm 0.07\end{array}$ & $\begin{array}{l}3.25^{\mathrm{ab}} \\
\pm 0.04\end{array}$ & $\begin{array}{l}3.20^{\mathrm{ab}} \\
\pm 0.08\end{array}$ & $* *$ \\
\hline Globulin (g/dl) & $\begin{array}{c}3.09 \\
\pm 0.10\end{array}$ & $\begin{array}{c}3.18 \\
\pm 0.05\end{array}$ & $\begin{array}{c}3.00 \\
\pm 0.10\end{array}$ & $\begin{array}{c}3.08 \\
\pm 0.12\end{array}$ & $\begin{array}{c}2.98 \\
\pm 0.06\end{array}$ & $\begin{array}{c}3.00 \\
\pm 0.06\end{array}$ & $\begin{array}{c}3.01 \\
\pm 0.10\end{array}$ & NS \\
\hline $\mathrm{A} / \mathrm{G}$ & $\begin{array}{c}1.08 \\
\pm 0.03\end{array}$ & $\begin{array}{c}0.97 \\
\pm 0.02\end{array}$ & $\begin{array}{c}1.11 \\
\pm 0.03\end{array}$ & $\begin{array}{c}1.04 \\
\pm 0.05\end{array}$ & $\begin{array}{c}0.99 \\
\pm 0.04\end{array}$ & $\begin{array}{c}1.08 \\
\pm 0.02\end{array}$ & $\begin{array}{l}1.06 \\
\pm 0.06\end{array}$ & NS \\
\hline $\mathrm{ALT}(\mathrm{U} / \mathrm{L})$ & $\begin{array}{l}23.21^{\mathrm{a}} \\
\pm 0.56\end{array}$ & $\begin{array}{l}22.74^{\mathrm{ab}} \\
\pm 0.54\end{array}$ & $\begin{array}{c}21.08^{\mathrm{bc}} \\
\pm 0.68\end{array}$ & $\begin{array}{l}20.06^{\mathrm{c}} \\
\pm 0.66\end{array}$ & $\begin{array}{l}22.06^{\mathrm{ab}} \\
\pm 0.23\end{array}$ & $\begin{array}{c}21.28^{\mathrm{abc}} \\
\pm 1.01\end{array}$ & $\begin{array}{l}22.13^{\mathrm{ab}} \\
\pm 0.15\end{array}$ & $*$ \\
\hline $\operatorname{AST}(\mathrm{U} / \mathrm{L})$ & $\begin{array}{l}36.09 \\
\pm 0.14\end{array}$ & $\begin{array}{l}35.84 \\
\pm 0.90\end{array}$ & $\begin{array}{l}33.41 \\
\pm 0.57\end{array}$ & $\begin{array}{l}33.91 \\
\pm 0.65\end{array}$ & $\begin{array}{l}37.12 \\
\pm 0.63\end{array}$ & $\begin{array}{l}35.96 \\
\pm 1.88\end{array}$ & $\begin{array}{l}36.76 \\
\pm 0.61\end{array}$ & NS \\
\hline
\end{tabular}

${ }^{\mathrm{a}-\mathrm{c}}$ means within each raw followed by different letters differ significantly, ${ }^{*}=\mathrm{P} \leq 0.05$,

$* *=\mathrm{P} \leq 0.01$ and $\mathrm{NS}=$ Non significant.

Data showed that the concentrations of serum cholesterol were higher in groups fed diets with 10 or $20 \%$ OCM without $\mathrm{NaHCO}_{3}(\mathrm{P} \leq 0.01)$ compared with other treatments. Similarly, Abdel-Aleem (2010) reported that as the level of supplementation with $\mathrm{NaHCO}_{3}$ increased from 0.5 to $1.0 \%$, plasma cholesterol concentration of growing rabbits was significantly decreased. Also, our results showed that rabbits fed diets with $10 \%$ OCM plus 0.25 or $0.50 \%$
$\mathrm{NaHCO}_{3}$ had the lowest $(\mathrm{P} \leq 0.01)$ triglycerides. Whereas, the rabbits received diets with 10 or $20 \%$ OCM without $\mathrm{NaHCO}_{3}$ had the lowest significant $(\mathrm{P} \leq 0.01)$ values of albumin among all treatments. In addition, ALT for rabbits fed diets supplemented with 10 and $20 \%$ OCM plus 0.25 or $0.50 \% \mathrm{NaHCO}_{3}$ recorded the lowest significant $(\mathrm{P} \leq 0.05)$ values compared with other groups. Azazi et al. (2018) observed that cholesterol and triglycerides in rabbits 
fed diet containing $10 \%$ OCM without or with $0.1 \%$ citric acid registered lower values compared to the other treatments. Total lipids, total protein, albumin, globulin, albumin /globulin ratio, and liver enzyme activity (ALT and AST) levels were not affected by the dietary treatments. Also, Mehrez and Mousa (2011) noted that total protein, albumin, globulin, cholesterol, urea-N, AST and ALT for rabbits fed diets containing olive pulp at levels of 20, 25 and $30 \%$ were not significantly affected. Furthermore, Walaa et al. (2016) reported that globulin significantly increased in rabbit diet contained $30 \%$ OCM with or without bentonite. While, the values of plasma cholesterol and total lipids for rabbits fed diets with $30 \%$ olive cake plus 0.5 and $1 \%$ bentonite are significantly reduced. Besides, Baker et al. (2019) reported that glucose and triglycerides levels in blood serum of rabbits decreased significantly $(\mathrm{P} \leq 0.05)$ due to treatments. However, feeding rabbit diet containing olive cake pulp as partial or complete substitution of wheat bran did not significantly affect the serum total protein, albumin, globulin, A/G, cholesterol, urea, creatinine, AST and ALT.

\section{Economical efficiency:}

Economical evaluation data are presented in Table (6). It is clearly that the lower price of OCM reflects positively on the price of the experimental diets. Our data revealed that feeding growing rabbits on diets containing 10 or 20 OCM decreased the total feed cost/ rabbit compared with those fed the control diet. Also, indicated that rabbits fed diets with $10 \%$ OCM without (T2) or with $0.25 \%$ (T3) $\mathrm{NaHCO}_{3}$ had the highest net revenue values (22.09 and 23.70 for $\mathrm{T} 2$ and T3, respectively) compared with the control group. Furthermore, the present results indicated an improvement in economical efficiency (EEf) or relative economical efficiency (REEf) for rabbits fed diets with $10 \%$ OCM without or with $\mathrm{NaHCO}_{3}$ (T2,T3 and T4) as compared with other groups. This could be due to the better FCR and best PI values which were obtained from rabbits fed diets supplemented with $10 \%$ OCM in comparison with the rest of the treatments. Our results agreed with Azazi et al. (2018) who revealed that the economical efficiency (EEf) and relative economical efficiency (REE) were higher in growing rabbits fed diets containing $10 \%$ OCM plus $0.1 \%$ citric acid than the other groups. Walaa et al. (2016) reported that feeding rabbits on diets with $30 \%$ OCM plus $1 \%$ bentonite gave the highest relative economical efficiency. Whereas, Baker et al. (2019) noted that the economical efficiency $(\mathrm{EE} \%)$ and relative economical efficiency (REE\%) were highest with the diet containing $25 \%$ olive cake pulp (OCP) followed by those containing 15 and $20 \%$ OCP compared with the control diet.

Table 6. Economical Efficiency of feeding rabbits the experimental diets

\begin{tabular}{|c|c|c|c|c|c|c|c|}
\hline \multirow[b]{3}{*}{ Parameters } & \multicolumn{7}{|c|}{ Treatments } \\
\hline & \multirow[b]{2}{*}{ Control } & \multicolumn{3}{|c|}{$10 \%$ Olive cake mail } & \multicolumn{3}{|c|}{$20 \%$ Olive cake mail } \\
\hline & & $\begin{array}{c}0.0 \% \\
\mathrm{NaHCO}_{3} \\
\end{array}$ & $\begin{array}{c}0.25 \\
\mathrm{NaHCO}_{3} \\
\end{array}$ & $\begin{array}{c}0.50 \\
\mathrm{NaHCO}_{3} \\
\end{array}$ & $\begin{array}{c}0.0 \% \\
\mathrm{NaHCO}_{3}\end{array}$ & $0.25 \mathrm{NaHCO}_{3}$ & $\begin{array}{c}0.50 \\
\mathrm{NaHCO}_{3}\end{array}$ \\
\hline $\begin{array}{l}\text { Weight gain (kg / } \\
\text { rabbit) }\end{array}$ & 1.166 & 1.165 & 1.253 & 1.136 & 0.972 & 0.979 & 1.012 \\
\hline Price $/ \mathrm{kg} \mathrm{LBW}(\mathrm{LE})^{1}$ & 35 & 35 & 35 & 35 & 35 & 35 & 35 \\
\hline $\begin{array}{l}\text { BWG revenue }(\mathrm{LE}) / \\
\text { rabbit }\end{array}$ & 40.81 & 40.78 & 43.86 & 39.76 & 34.02 & 34.27 & 35.42 \\
\hline $\begin{array}{l}\text { Feed consumed }(\mathrm{kg} / \\
\text { rabbit })\end{array}$ & 4.963 & 4.296 & 4.592 & 4.365 & 4.168 & 4.144 & 4.248 \\
\hline $\begin{array}{l}\text { Price/kg feed } \\
\text { consumed (LE) }\end{array}$ & 4.71 & 4.35 & 4.39 & 4.43 & 4.11 & 4.15 & 4.19 \\
\hline Total feed cost (LE) & 23.38 & 18.69 & 20.16 & 19.34 & 17.13 & 17.20 & 17.80 \\
\hline Net revenue $\mathrm{LE}^{2}$ & 17.43 & 22.09 & 23.70 & 20.42 & 16.89 & 17.07 & 17.62 \\
\hline $\begin{array}{l}\text { Economical } \\
\text { Efficiency (EEf) }\end{array}$ & 0.746 & 1.182 & 1.176 & 1.056 & 0.986 & 0.992 & 0.989 \\
\hline Relative $\operatorname{EEf}^{4} \%$ & 100 & 158.45 & 157.64 & 141.55 & 132.17 & 133.98 & 132.57 \\
\hline
\end{tabular}

\section{CONCLUSIONS}

Results from this study indicated that inclusion of olive cake meal (OCM) in growing rabbit's diet at a level $10 \%$, with or without sodium bicarbonate, may be useful and have significant impact on growth performance, carcass characteristics, blood components and economical efficiency.

\section{REFERENCES}

Abd EL-Galil, K., 2001. Utilization of olive pulp meal in feeding growing rabbits. J. of Agriculture Sci. Mansoura University 26; 727-736.

Abdallah, A.G., M.M. Beshara and A.F. Ibrahim, 2015. Effect of different levels and sources of 
dietary fiber on productive and economical performance in local laying hens 1- during laying period. Egypt. Poultry Sci., 36, (I): 97-120.

Abdel-Aleem, A.M.E. 2010. Effect of Dietary Levels of Sodium Bicarbonate and Ascorbic Acid on Performance of Growing Rabbits Under Hot Climate Conditions. M.Sc. Thesis, Fac., Agric., Fayoum, Cairo University.

Abou-Ela, S. S, F. A. F. Ali, A. Madi and M. R. A. EL-Naby. 2011. Olive cake meal as partial or complete substitute for clover hay in growing rabbit diets. Egyptian Journal of Nutrition and Feeds. 14; 109-119.

Agriculture Ministry Decree. 1996. The standard properties for ingredients, feed additives and feed manufactured for animal and poultry. El-Wakaee El-Masria press Cairo, Egypt. No. 192: 95.

Ahmed, E., R. Smtthard and M. Ellis. 1990. Activities of enzymes of the pancreas, and the lumen and mucosa of the small intestine in growing broiler cockerels fed on tannincontaining diets. British Journal of Nutrition. 65; 189-197.

A.O.A.C. 2000. Official Methods Of Analysis. $17^{\text {th }}$ ed., Published by the A.O.A.C., Washington, D.C., USA.

Azazi, I. A., S. Gadelrab, H. A. EL-Komy and A. S. Ahmed. 2018. Growth Performance and Feed Utilization of Growing Rabbits Fed Diets Containing Olive Cake Meal Supplemented With or Without Citric Acid. Egyptian Journal of Rabbit Science, 28, (2): 241 -262.

Bakr, E. O. A., M. M. Shetaewi and A. E. M. I. ElDesoky. 2019. Effect of Olive Cake Pulp as A Partial or A Complete Substitute of Wheat Bran in Growing Rabbits' Diet on Growth Performance, Carcass Traits and Blood Constituents under North Sinai Conditions. J. Animal and Poultry Prod., Mansoura Univ., Vol.10, (3): 83 - 88.

Balnave, D. and A.G. Oliva. 1991. The influence of sodium bicarbonate and sulfur amino acids on the performance of broilers at moderate and high temperatures. Aust. J. Agri. Res., 42; 1385-1397.

Carraro, L., A. Trocino, and G. Xiccato. 2005. Dietary supplementation with olive stone meal in growing rabbits. Ital. J. Anim. Sci., 4, (3): 88-90.

Cheeke, P.R. 1987. Rabbit Feeding and Nutrition. Academic Press, Orlando, Florida USA. 376p.

Cheeke, P. R., N. M. Patton and G. A. Tempelton. 1982. Rabbit Production. $5^{\text {th }}$ Edition, Interstate Printers and Publishers, Danville II., USA.

Dal Bosco, A., C. Castellini, R. Cardinali, E. Mourvaki, L. Moscati, L. Battistacci, M. Servili and A. Taticchi. 2007. Olive cake dietary supplementation in rabbit: immune and oxidative status. Ital. J. Anim. Sci., 6; 761-763.

Dorbane, Z., S.A. Kadi, D. Boudouma, M. Berchiche, C. Bannelier and T. Gidenne. 2016. Nutritive value of crude olive cake (olea europaea L.) for growing rabbit. $11^{\text {th }}$ World Rabbit Congress. Kingdao, France. 381 - 384.
Duncan, D. B.1955. Multiple Range and Multiple FTest. Biometrics, 11; 1-42.

El-Kerdawy, D.M.A. 1997. Olive pulp as a new energy source for growing rabbits. Egyptian J. Rabbits Sci., 7; 1-12.

El-Sheikh, S. E. M. 2012. Utilization enhancement of olive cake in local laying hen diets by using polyethylene glycol Proc. $13^{\text {th }}$ Scientific Conference of Animal Nutrition, 15, (1): 251263.

Feed composition for animal and poultry feed stuff used in Egypt. (2001). Technical pullrtil No. Central lab. For food and feed; Ministry of Agriculture, Egypt.

Heuzé ,V., G. Tran, F. Lebas and A. Gomez Cabrera. 2014. Olive oil cake and by-products. Feedipedia.org. A programme by INRA, CIRAD, AFZ and FAO. J. Animal and Poultry Prod., Mansoura Univ., Vol.10, (3): 83 - 88.

Jyothi, V. and S. Sumathi. I995. Effect of alkali treatments on the nutritive value of common bean (Phaseolus vuigaris). Plant Foods for Human Nutrition 48;193-200.

Kim, H. S. and D. D. Miller. 2005. Proline-rish protein oderate the inhibitory effect of tea on iron absorption in rat. J. of Nutrition, 135; 532-537.

Mahmood, S., M. A. Khan, M. Sarwar and M. Nisa. 2006. Chemical treatments to reduce anti-nutritional factors in Salseed (Shorea robusta) Meal: Effect on nutrient digestibility in colostomized pullets and intact broilers. Poult. Sci. $85 ; 2207-2215$.

Mahmood, S., R. Smithard and M. Sarwar. 1997. Effects of salseed (Shorea robustal) tannins, restricted feed intake and age on relative pancreas weight and activity of digestive enzymes in male Broilers. Anim. Feed Sci. Technol. 65; 215-230.

Mahmood, S., M. Ajmal Khan, M. Sarwar, M. Nisa, W. S. Lee, S. B. Kim, T. Y. Hur, H. J. Lee and H. S. Kim. 2007. Use of Chemical Treatments to Reduce Tannins and Trypsin Inhibitor Contents in Salseed (Shorea robusta) Meal. Asian-Aust. J. Anim. Sci. 20, (9):1462-1467.

Manning, P. J., D. H. Ringler and C. E. Newcomer. 1994. The Biology of the laboratory rabbit, 2nd ed. Academic press Inc., San Diego, California, U. S. A.

Mehrez, A.Z. and M.R.M. Mousa. 2011. Growth performance of rabbits fed olive pulp in North Sinai, Asian Journal of Animal Production Science. 5, (5): 317-329.

Moic, B., V. Pavic, I. Vnucec, Z. Prpic, A. Kostelic and V. Susic. 2007. Effect of olive cake on Naily gain, carcasses characteristics and chemical composition of lamb meat. C.zech. J. Anim. Sci., 52; 31-36.

Mousa, M. R. M. and A.M. Abd El-Samee. 2002. Effect of olive pulp feeding on the growth performance and some related blood biochemical changes of growing rabbits under semi arid conditions. Egypt. J. Rabbit Sci., 12; 59-68. 
Mvan, S and J. Suresh. 2014. Effect of citric acid supplementation on growth and nutrient utilization in the diet of crossbred pigs. Indian J. Anim. Res., 48, (4): 395 - 397.

North, O. M. 1981. Commercial Chicken. Production annual. 2nd Edition, AV., Publishing company I.N.C. Westpost Connicticut, USA.

Rowghani, E., M.J. Zamiri and A.R. Seradj. 2008. The chemical composition, rumen degradability, in vitro gas production, energy content and digestibility of olive cake ensiled with additives. Iran. J. Vet. Res., 9; 13-221.

Rupić, V., J. Škrlin, S. Mužic, V. Šerman, N. Stipiæ and L. Baèar-Huskiæ. 1999. Protein and Fat Concentrations in the Blood Serum of Rabbits
Fed Different Quantities of Dried Olive Cake. Acta Veterinaria Brno, 68, (2): 91-98.

Santos-Buelga, C. and A. Scalbert. 2000. Proanthocyanidins and tannin - like compounds nature, occurrence, dietary intake and effects on nutrition and health. J. of Sci .Food Agric. 80; 1094-1117.

SPSS. 2018. User's guide: statistics. Version 22. SPSS Inc. Chicago, IL, USA.

Walaa A. Salama, M. M., Basyony; A. Marwa, Suliman, R. I. M. Matari and A. M. Hanan Hassanein. 2016. Effect of Feeding Olive Cake Supplemented With or Without Bentonite on Performance of Growing Rabbits. Egyptian Journal of Rabbit Science, 26, (2): 211-230.

\section{تأثثر إستخدام تفل الزيتون مع /أو بدون بيكربونات الصوديوم على الكفاعة الإنتاجية للأزانب النيوزيلندي البيضاء

مدمرا إهيم عاطف عزدازي' ، هيام سيد عبد الحليم'، صابر صبحي جاد الرب'، حمدي محمد الكومي'، عادل سيد أحمد'، مجدي محمد

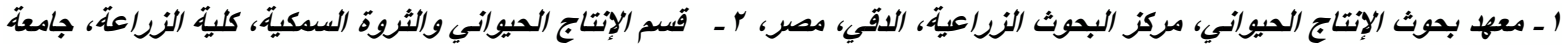

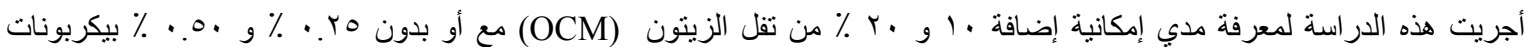

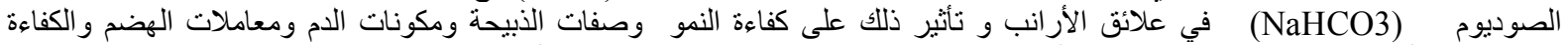

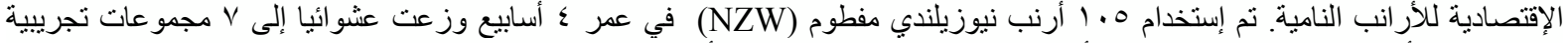

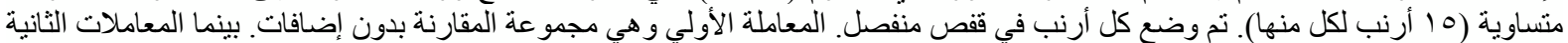

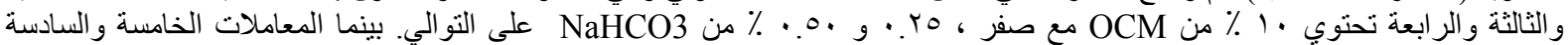

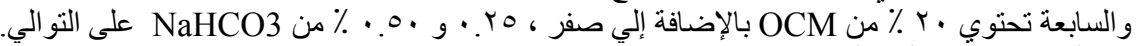

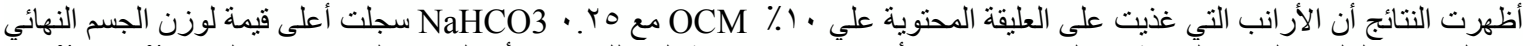

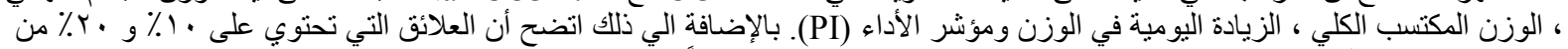

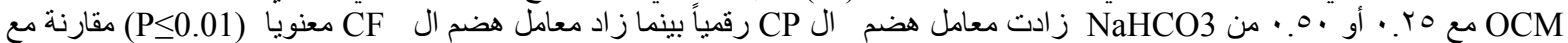

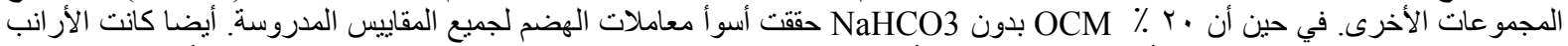

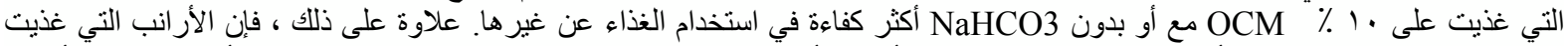

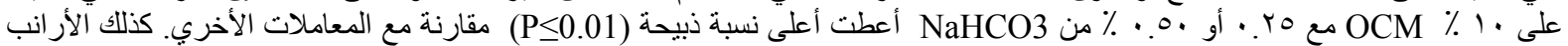

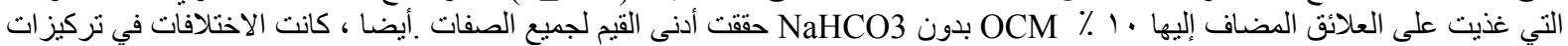

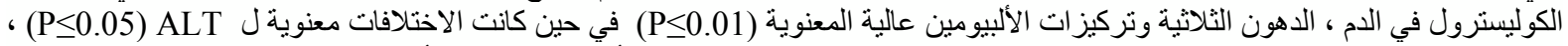

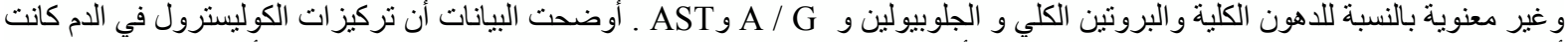

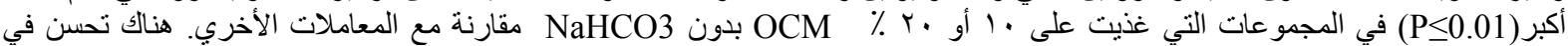

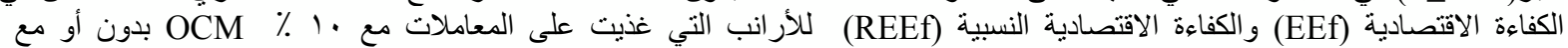
NaHCO3

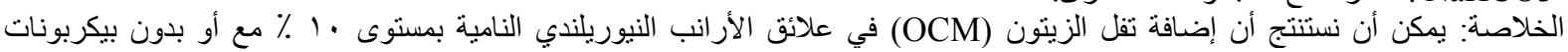
الصوديوم مفيد ويؤثر بشكل جيد على كفاءة النمو وصفات الزئل الذبيحة ومكونات الدم و الكفاءة الاقتصنادية. 